\title{
Pollination Biology of the Genus Artocarpus, Moraceae
}

\author{
Kuniyasu MOMOSE Center for Ecological Research, Kyoto University, Otsu 520-0105, Japan* \\ Aya HATADA Faculty of Science, Kyoto University, Kyoto 606-8501, Japan \\ Ryohei YAMAOKA Department of Applied Biology, Kyoto Institute of Technology, Kyoto 606-8501, Japan \\ Tamiji INOUE Center for Ecological Research, Kyoto University, Otsu 520-0105, Japan
}

\begin{abstract}
The pollination biology of Artocarpus odoratissimus and A. integer (Moraceae) was studied in Sarawak, Malaysia. Female and male heads of $A$. odoratissimus secreted liquid rewards containing fructose in nighttime, and were visited by diverse nocturnal insects (18 families of 4 orders) including flies, nitidulid beetles, moths and cockroaches. In $A$. integer, male heads offered only pollen as rewards, and female heads offered liquid rewards containing protein. They were visited by diverse nocturnal insects ( 11 families of 5 orders). The evidence for insect pollination of these two species of Artocarpus was from the existence of rewards, and that some insects carrying pollen grains were collected on female heads.
\end{abstract}

Key Words: Artocarpus / Moraceae / insect pollination / nocturnal flower / protein reward / Sarawak

The family Moraceae includes 48 genera, but pollination systems are known in only a few genera. The temperate genus, Morus, is considered to be wind-pollinated, because large amount of pollen is found in the air (Kinjo et al., 1988). Some tropical genera in Australia (Streblus and Malaisia; Williams \& Adam, 1993) and in the Neotropics (Chrorophora and Trophis; Bawa \& Crisp, 1980; Bullock, 1994) are also wind-pollinated. Ficus is the only genus which has been revealed to be pollinated by animals (fig wasps; Galil \& Eisikowitch, 1968).

The genus Artocarpus (Moraceae) is distributed in Indomalesia and includes 31 species (Primack, 1983). Little information on pollination systems has been reported. Corner (1952) suggested that the genus Artocarpus includes both wind-pollinated and insect-pollinated species. If his suggestion is revealed to be true, Artocarpus is one of the very rare examples of both wind- and insect-pollinated species being included in the same genus (like Espeletia, Asteraceae; Berry \& Calvo, 1989), so is good material for studying shift of pollination systems.

However, the evidence for insect pollination in Artocarpus is insufficient, because nobody has reported that insects carrying pollen grains visit female heads of Artocarpus. Corner (1952) noted that male heads of $A$. heterophyllus (jackfruit, cultivated), A. integer (cempedak, cultivated), and $A$. dadah were visited by flies and beetles in Malaya. He estimated that Malayan A. rigidus and A. elasticus were wind-pollinated, because male heads gave off clouds of pollen (ballistic pollen release). Primack (1983) observed A. elasticus, A. kemando, and A. odoratissimus in Sarawak, and found bees only on male heads. Male heads of the jackfruit, $A$. heterophyllus, cultivated in Australia were visited by flies,

*Present address: Graduate School for Asian and African Area Studies, Kyoto University, Kyoto, 606-8501, Japan 
Drosophyla immigrans (Moncur, 1985). Brantjes (1982) reported that male heads of the breadfruit, $A$. altilis (= A. communis), cultivated in Brazil offered nectar, and were visited by bees, Trigona fulventris var. guianae. However, Primack (1983) noted that $A$. communis cultivated in Sarawak is wind-pollinated because of ballistic pollen release, and Singh et al. (1963) stated that fruits of $A$. altilis (=A. communis) cultivated in India set without pollination.

In this paper, we collected flower visitors and floral rewards from male and female heads of $A$. odoratissimus (terap or pingan) and $A$. integer (cempedak), examined pollen deposition on insects collected on flowers, and analyzed chemical contents of floral rewards, in order to show evidences of insect pollination of Artocarpus.

\section{MATERIALS AND METHODS}

Field observations and samplings were carried out in secondary forests around Lambir Hills National Park, Sarawak, Malaysia ( $4^{\circ} 2^{\prime} \mathrm{N}, 113^{\circ} 50^{\prime} \mathrm{E}, 150 \mathrm{~m}$ in altitude).

Artocarpus odoratissimus Blanco (voucher: T. Nagamitsu 156, KYO, SAR) is distributed in Borneo and the Philippines, and common in secondary forests. The tree is monoecious, up to $25 \mathrm{~m}$ tall. The male and female heads are similar in shape, size and location; ellipsoid, $9 \mathrm{~cm} \times 3.5 \mathrm{~cm}$, and located in leaf axes. The male head is green turning brown, and the female head is green in color of flowering. In Sarawak, it flowers at intervals of 2 or more years (K. Momose, personal observations).

Artocarpus integer (Thunb.) Merr. (voucher: K. Momose 7326, KYO, SAR) is distributed in the wild in Borneo, Sumatra, Sulawesi, Moluccas, and New Guinea, and widely cultivated in Southeast Asia. In Borneo, it is locally common in lowland dipterocarp forests. The tree is monoecious, up to 25 $\mathrm{m}$ tall. The male head is cylindrical, $3 \mathrm{~cm} \times 1 \mathrm{~cm}$, green, in the leaf axis. The female head is ellipsoid, $3.5 \mathrm{~cm} \times 1.5 \mathrm{~cm}$, green, cauliflorous. In Sarawak, it usually flowers at intervals of 4 or more years (S. Sakai et al., unpublished).

Flower visitors of Artocarpus odoratissimus were collected at 20:00, 1:00, 6:00, 11:00 and 16:00, May 5-6, 1996. At each collecting time, flower visitors alighted on flowers were collected on two male heads and two female heads. The observed tree was located in a secondary forest. Flower visitors of Artocarpus integer were collected at 20:00-22:00, 4:00-6:00 and 12:00-14:00, May 22-23, 1996. At each collecting time, insects that visited flowers within two hours were collected on three male heads and three female heads. The observed tree was planted in a secondary forest near an Iban long house, ca. $2 \mathrm{~km}$ apart from a primary dipterocarp forest. The owner of the tree stated that the seed was originally brought from the primary dipterocarp forest near the long house. After flower visitors were pinned, we checked pollen depositions under a microscope.

Liquid rewards were collected using micro-capillaries (Drummond Scientific Co.). Reward samples were analyzed by high performance liquid chromatography (Column: COSMOSIL 5NH2MS; Fluent: Acetonitrile / water $=75 / 25$, Flow rate: $1.0 \mathrm{ml} / \mathrm{min}$., Detection: RI). Protein was quantified in micro protein assay (CBBG-250 method).

\section{RESULTS}

In 1996, a population of Artocarpus odoratissimus flowered in May 1 - June 14. The longevity of male and female heads was more than 3 days (upper limit was not obtained). Male and female heads of $A$. odoratissimus started to emit odors and liquid rewards (for anatomical study of nectary, see Moncur 1985) from 19:00, and were visited by diverse insects: nitidulid beetles, blatterid 

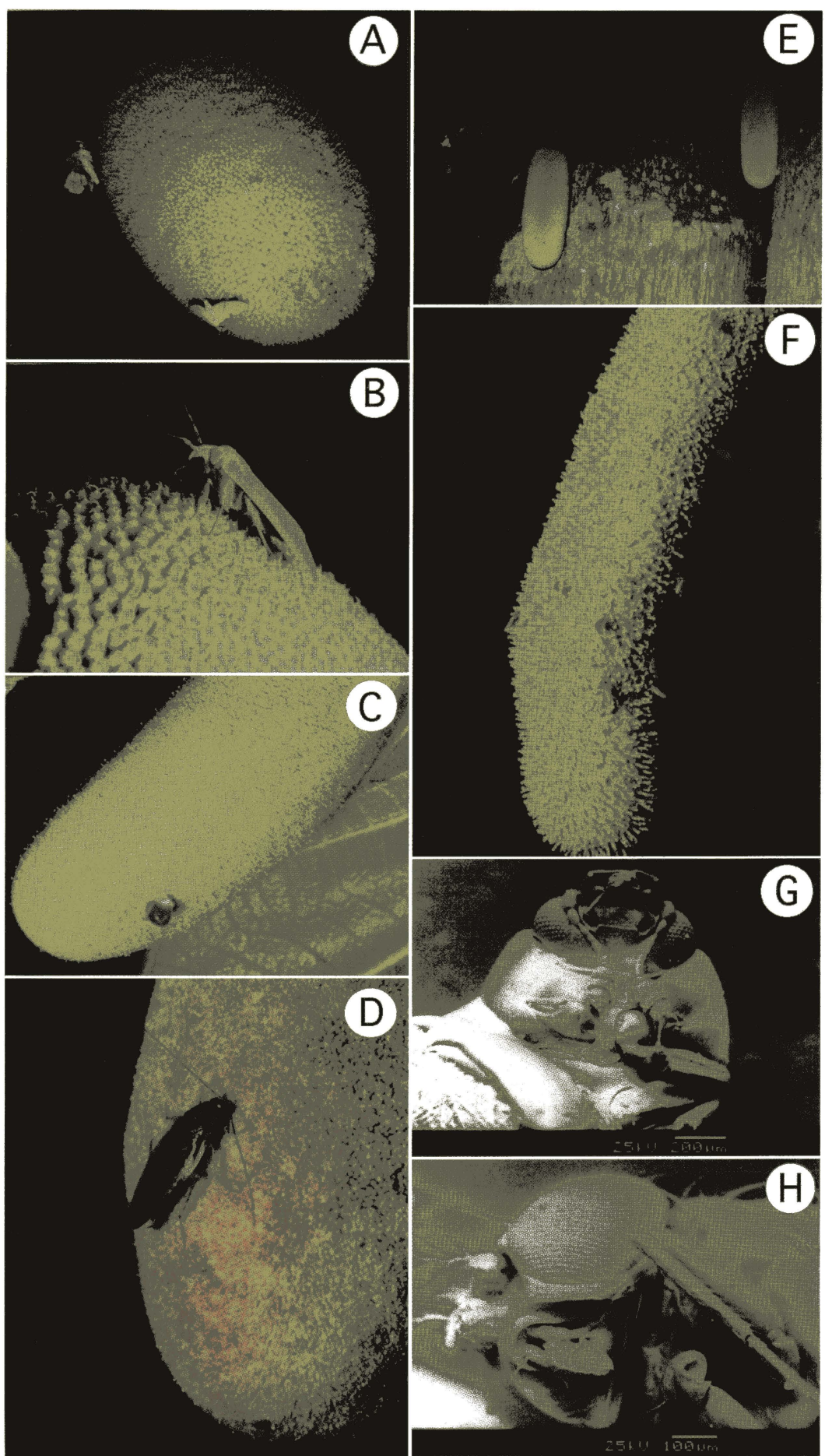

Fig. 1. Flowers and flower visitors of Artocarpus odoratissimus and A. integer. A. geometrid moth visited a femal head of $A$. odoratissimus. B. A pyralid moth visited a femal head of $A$. odoratissimus. C. A flesh male head of $A$. odoratissimus with a drop of liquid reward. D. A blattellid cochroach (center) and a nitidulid beetle (lower) visited a male head of $A$. odoratissimus. E. Famale heads of $A$. integer. F. Flies of multiple families visited a male head of $A$. integer. G. A nitidulid beetle collected on a female head of $A$. odoratissimus. Pollen grains are found at ventral parts of the head and the thorax. H. A drosophilid fly collected on a female head of $A$. odoratissimus. Pollen grains are found on the eye and the forelegs. 
Table 1. Insect families collected from female and male heads of Artocarpus odoratissimus and A. integer. No. insects carrying pollen grains / No. collected insects.

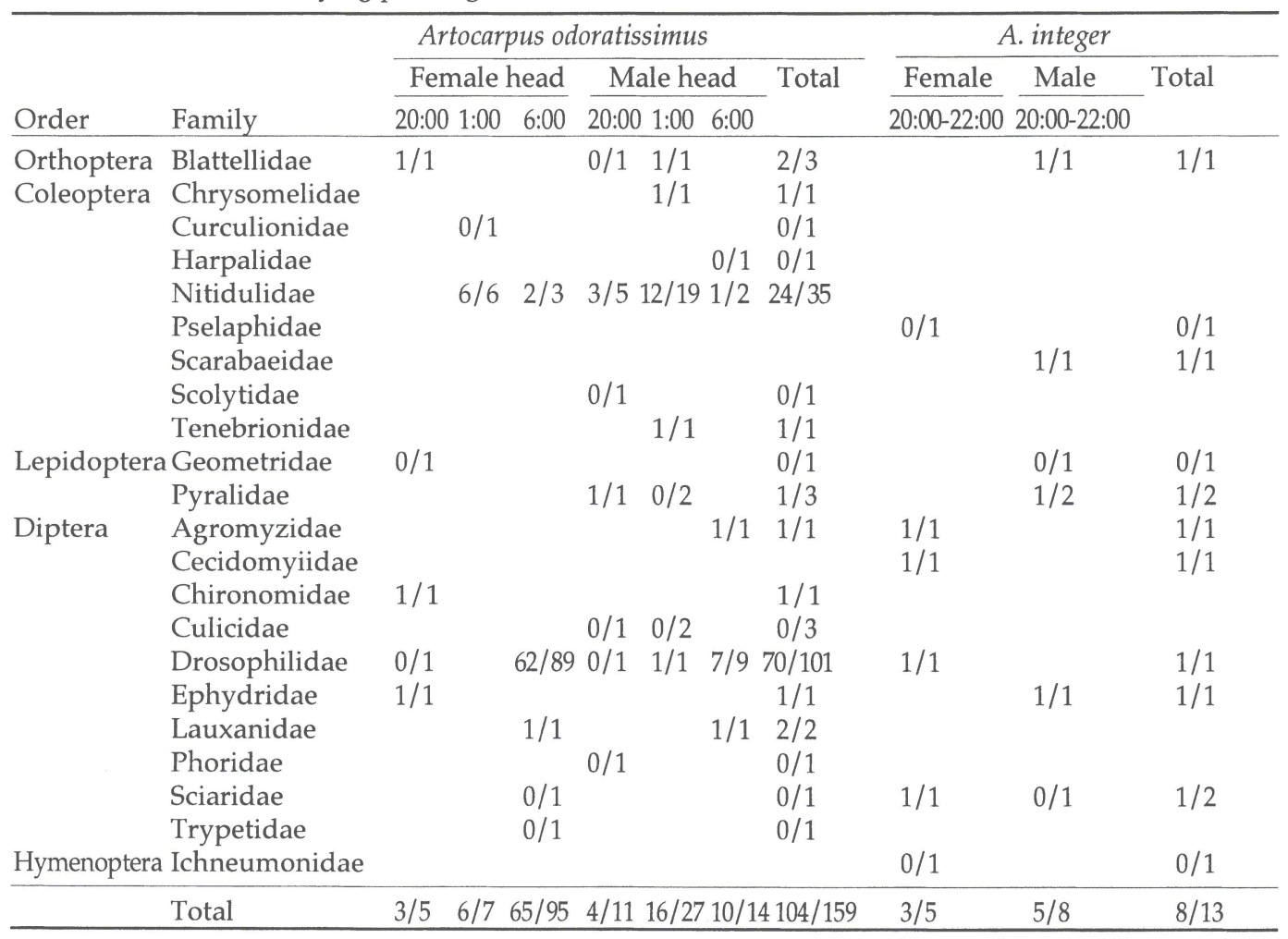

cockroaches, pyralid moths and geometrid moths (Table 1, Figs. 1. A, B, C, D). Although we could not determine the time when reward secretion was finished, reward was mostly dried up in the next morning (6:00). In the morning (6:00), drosophilid flies and nitidulid beetles visited flowers and fed on the remaining reward. In daytime (11:00 and 16:00), no visitors were found. Ballistic pollen release was not observed in male heads.

Pollen depositions were observed on $58 \%(\mathrm{~N}=52)$ of insects collected from male heads and $69 \%$ $(\mathrm{N}=107)$ of insects collected from female heads (Table 1, Figs. 1. G, H). The reward contained fructose $(8.1 \mathrm{mg} / \mathrm{ml}$ in a male head, $1.5 \mathrm{mg} / \mathrm{ml}$ in a female head; Fig. 2), but glucose and sucrose were not included.

In 1996, a population of Artocarpus integer flowered in May 4 - June 1. The longevity of male and female heads was more than 3 days (upper limit was not obtained). Male and female heads of $A$. integer started to emit odors from 19:00, and were visited by diverse insects: flies of various families and blatterid cockroaches (Table 1, Figs. 1. E, F). In male heads, no liquid reward was secreted and flower visitors fed on pollen. Moths were collected on male heads, but they seemed to obtain no rewards. In female heads, liquid reward was secreted and fed on by flower visitors. In the morning (4:00-6:00) and daytime (12:00-14:00), odors were not detectable, no reward was secreted in female heads, and no visitors were found on male and female heads. Ballistic pollen release was not observed in male heads.

Pollen depositions were observed on $63 \%(\mathrm{~N}=8)$ of insects collected from male heads and $60 \%$ of insects $(\mathrm{N}=5)$ collected from female heads (Table 1$)$. The liquid reward contained protein $(2.3 \mathrm{mg}$ $/ \mathrm{ml}$ ), but did not contain sucrose, fructose nor glucose (Fig. 2). 


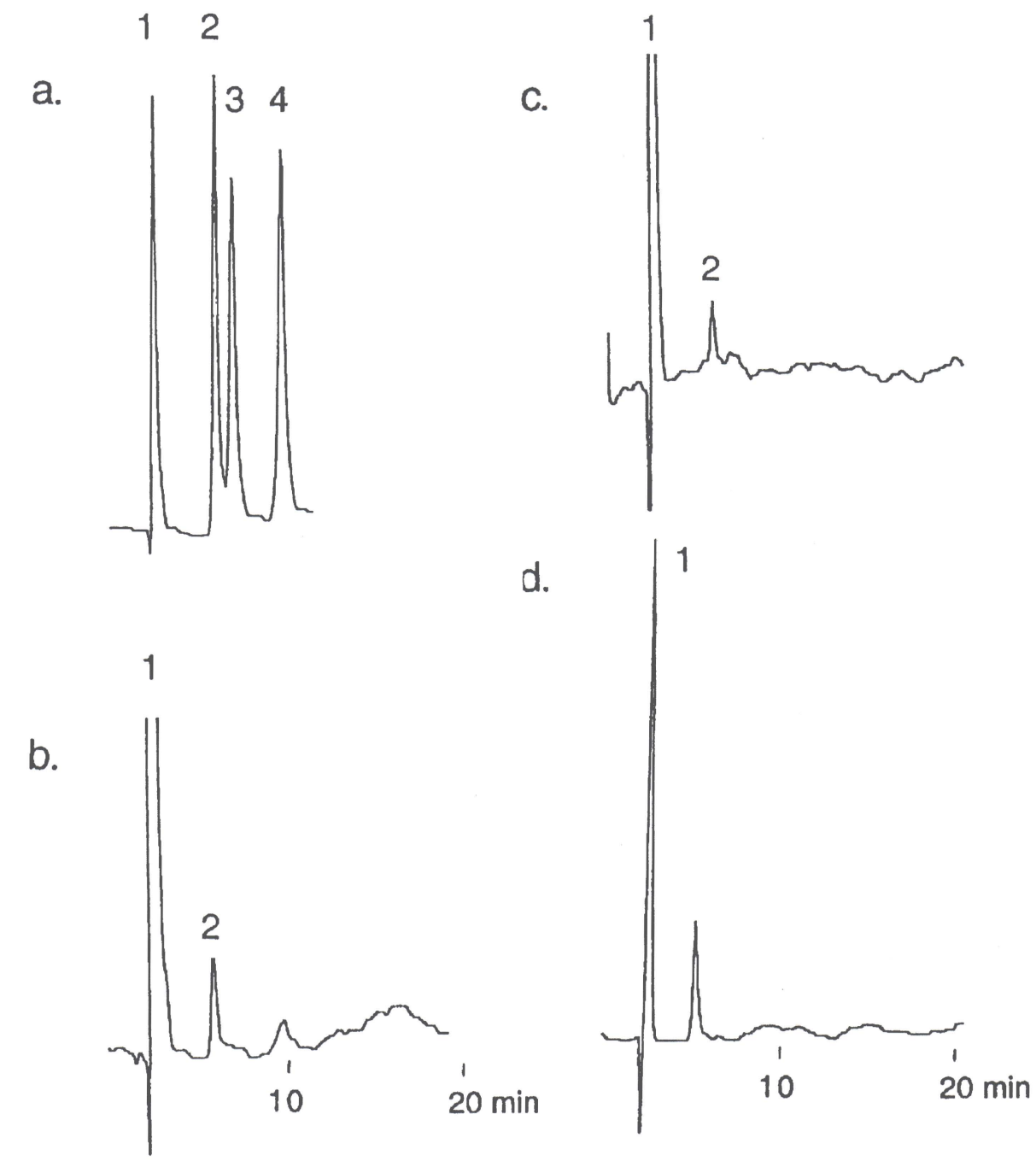

Fig. 2. HPLC analyses of liquid rewards of Artocarpus odoratissimus and A. integer. (Column: COSMOSIL 5NH2-MS; Fluent: Acetonitrile $/$ water $=75 / 25$; Flow rate: $1.0 \mathrm{ml} / \mathrm{min}$, Detection: RI). a. Standard solution containing fructose, glucose and sucrose $(30 \mathrm{mg} / \mathrm{ml}$ respectively); $1: \mathrm{H}_{2} \mathrm{O}, 2$ : fructose (6.0 min.), 3: glucose (7.0 $\mathrm{min}$.), 4: sucrose (9.8 min.). b. Liquid reward collected from male heads of $A$. odoratissimus. A peak at 6.0 min. matched with the peak of fructose in the standard solution. c. Liquid reward collected from female heads of $A$. odoratissimus. A peak at 6.0 min. matched with the peak of fructose in the standard solution. $\mathrm{d}$. Liquid reward collected from female heads of $A$. integer. A peak at $5.2 \mathrm{~min}$. was revealed to be of protein from protein assay (CBBG-250 method).

\section{DISCUSSION}

Although insect visitations to Artocarpus flowers have been reported (Corner, 1952; Brantjes, 1982; Primack, 1983' Moncur, 1985), systematic observations in nighttime have not been carried out, and flower visitors have only been observed on male heads. Insect pollination of Artocarpus has not yet been demonstrated, because nobody reported that insects carrying pollen grains visited female heads. This study provides evidences that demonstrate that $A$. odoratissimus and $A$. integer provide rewards to attract diverse nocturnal insects and are pollinated by them. First, odors were emitted and rewards 
were offered in nighttime. Second, male and female heads were visited by diverse insects in nighttime, and ones carrying pollen grains were collected on female heads.

It seems that no or few pollen grains of $A$. odoratissimus and $A$. integer are carried by wind, because ballistic pollen release was not observed. However, experimental studies on the role of wind as a pollen vector in $A$. odoratissimus and $A$. integer, as well as $A$. rigidus and $A$. elasticus, which have been suggested to be wind-pollinated (Corner, 1952), are required.

Little information is available on the pollination of tropical nocturnal flowers. Most neotropical nocturnal flowers are pollinated by specialized pollinators like bats, moths or beetles (Bawa, 1990). In contrast, the two Artocarpus species studied in this study were pollinated by diverse nocturnal insects in a number of insect families of several orders (moths, cockroaches, flies and beetles). According to recent studies, some of these insects were also found on other nocturnal flowers in lowland dipterocarp forests: Uvaria (Annonaceae) is pollinated by cockroaches (Nagamitsu \& Inoue, 1997) and Gnetum (Gnetaceae) is pollinated by flies or moths (Kato et al., 1995); but flower visitors of Artocarpus are much more diverse.

Artocarpus odoratissimus secreted a liquid reward containing fructose $(0.15-0.8 \mathrm{mg} / \mathrm{ml})$. Nectar in diurnal flowers and moth- or bat-pollinated nocturnal flowers contain a much higher density of sugars (2.2-30.5 mg / $\mathrm{ml}$ in flowers of Lambir, Sarawak; A. Hatada et al unpublished) in a mixture of fructose, glucose and sucrose (Freeman et al., 1992, A. Hatada et al unpublished). The liquid reward of $A$. odoratissimus is characterized by the thin sugar content and the simple sugar component.

Male heads of Artocarpus integer do not have liquid rewards, and only pollen is offered to visitors. Female heads offer protein-rich liquid rewards without sugar. The reward of $A$. integer is unique in two points. First, the phenomenon that only female flowers have a liquid reward is very strange. Second, although proteins or amino acids are often contained in nectar (Baker, 1986), proteinrich liquid rewards without sugar have not been reported.

In unisexual flowers, if only pollen is offered as a reward in male flowers, female flowers usually deceive insects as observed in Myristica (Armstrong \& Irvine, 1989), Begonia (Agren \& Schemske, 1991), Sterculia and Diospyros (K. Momose, personal observations). In these cases, insects stay on female flowers during a much shorter time than on male flowers. Unlike female flowers of Myristica, etc., female heads of Artocarpus contain many stigmas. Thus, if pollinators stay for a long time on female heads, successful pollination of multiple stigmas is to be expected. Liquid reward is considered to encourage visitors to stay long on female heads.

When the reward of male flowers is only pollen, pollinators mainly obtain nitrogen (protein) from male flowers rather than energy (carbohydrate) (Roubik, 1989). The protein-rich liquid reward of female heads of Artocarpus integer seems to offer similar resources for pollinators as the pollen of male flowers.

ACKNOWLEDGMENTS A. Enggan, Rh. Aji, Sg. Liam, Miri, Sarawak allowed us to study on his cempedak tree. H. S. Lee, A. A. Hamid, Forest Department Sarawak, and K. Ogino, Ehime University, kindly supported the research project. K. Nomura and M. Kakiuchi, Kyoto Institute of Technology, helped our chemical analysis of rewards. M. Kato, Kyoto University, helped insect identification. Y. Kusuoka, Lake Biwa Museum of Shiga Prefecture, allowed to use SEM at Lake Biwa Museum. A. Tuji, Kyoto University, helped observations of pollen grains. P. S. Ashton, Harvard University, reviewed the manuscript. We thank these persons. This study was partly supported by the Japan Ministry of Education, Science and Culture for International Scientific Research Grant (\#04041067, 06041013 and 09N1501). 


\section{REFERENCES}

Agren, J. \& Schemske, D. W. 1991. Pollination by deceit in a Neotropical monoecious herb, Begonia involucrata. Biotropica 23: 235-241.

Armstrong, J. E. \& Irvine, A. K. 1989. Floral biology of Myristica insipida R. Br. (Myristicaceae), a distinctive beetle pollination syndrome. American Journal of Botany 76: 86-94.

Baker, H. G, \& Baker, I. 1986. The occourence and significance of amino acids in floral nectar. Plant Systematics and Evolution 151: 175-186.

Bawa, K. S. \& Crisp, J. E. 1980. Wind-pollination in the understory of a rainforest in Costa Rica. Journal of Ecology 68: 871-876.

Bawa, K. S. 1990. Plant-pollinator interactions in tropical rain forests. Annual Review of Ecology and Systematics 21: 399-422.

Berry, P. E. \& Calvo, R. N. 1989. Wind pollination, self-incompatibility, and altitudial shifts in pollination systems in the High Andean genus Espeletia (Asteraceae). American Journal of Botany 76: 1602-1614.

Brantjes, N. B. M. 1982. Nectar and the pollination of bread fruit, Artocarpus altilis (Moraceae). Acta Botanica Neerlandica 30: 345-352.

Bullock, S. H. 1994. Wind pollination of neotropical dioecious trees. Biotropica 26: 172-179.

Corner, E. J. H. 1952. Wayside trees of Malaya. II. Government Printing Office, Singapore.

Freeman, C. E., Worthington, R. D. \& Jackson, M. S. 1992. Floral nectar sugar compositions of some south and southeast Asian species. Biotropica 23: 568-574.

Galil, J. \& Eisikowitch, D. 1968. On the pollination ecology of Ficus sycomorus in East Africa. Ecology 49: 259-269.

Kato, M., Inoue, T. \& T. Nagamitsu, 1995. Floral and pollination biology of Gnetum (Gnetaceae) in a lowland mixed dipterocarp forest in Sarawak. American Journal of Botany 82: 862-868.

Kinjo, Y., Simoji, K., Miyagi, M., Fukuhara, H., Nakamura, H., Kaneshima, H., \& Saito, A. Air-born pollens in Okinawa (Japan). Japanese Journal of Allergology 36: 1068-1074.

Moncur, M. W. 1985. Floral ontogeny of the jackfruit, Artocarpus heterophyllus (Moraceae). Australian Journal of Botany 33: 585-594.

Nagamitsu, T. \& Inoue, T. 1997. Cockroach pollination and breeding system of Uvaria elmeri (Annonaceae) in a lowland mixed-dipterocarp forest in Sarawak. American Journal of Botany 84: 208-213.

Primack, R. B. 1983. Forester's guide to the Moraceae of Sarawak. Forest Department, Sarawak, Kuching, Malaysia

Roubik, D. W. 1989. Ecology and Natural History of Tropical Bees. Cambridge University Press, Cambridge.

Singh, S., Krishnamurthi, S., \& Katyal, S. L. 1963. Fruit Culture in India. Indian council for Agricultural Research, New Delhi, India.

Williams, G. \& Adam, P. 1993. Ballistic pollen release in Australian members of the Moraceae. Biotropica 25: 478-480. 
百瀬邦泰, 畑田彩, 山岡亮平, 井上民二 Artocarpus 属（クワ科）の送粉様式に ついて

マレーシア，サラワク州でArtocarpus odoratissimus，A. integerの 2 種について送粉過程を調べた。A. odoratissimusでは, 雄花序, 雌花序の両方で, 夜間にフルクトースを含んだ報酬が分泌され，ガ，ゴキブ リ，八エ，ケシキスイなど 4 目 18 科の昆虫が訪花した。A. integerでは雄花序は花粉のみが報酬で, 雌花 序では夕ンパク質を含んだ報酬が分泌されていた。A. integer の雌雄の花序には, 夜間に 5 目 11 科の昆虫 が訪花した。これら 2 種は, 報酬が存在することと, 雌花序でそれぞれの花粉を付着させた昆虫が採集さ れたことから，虫媒であることが証拠づけられた。 